\title{
The use of computerized echoencephalography after recent head injury presenting to the accident and emergency department
}

\author{
P. L. MILSOM, L. H. BUTCHER \& A. K. MARSDEN \\ Department of Accident and Emergency Medicine, Pinderfields General Hospital, Wake- \\ field, England
}

\section{SUMMARY}

In a review of the records of 874 head-injured patients who had an echoencephalogram in the Accident and Emergency Department, two patients with apparently 'minor' head injury subsequently developed an extradural haematoma. Both would have been diagnosed earlier if the results of the echoencephalogram had been used to influence their referral to the nearest neurosurgical department before the onset of any neurological deterioration.

For those patients who arrive in the Department in coma, failure to detect any midline shift should not delay urgent referral for a CT scan. Such patients may be harbouring either bilateral haematomas or a very large single haematoma causing more than the 14-mm maximum shift recordable by the equipment.

\section{INTRODUCTION}

Of the one million head-injured patients who attend accident and emergency (A\&E) departments each year, as many as $22 \%$ may be admitted to hospital and of these only a small proportion (about 5\%) transferred to a neurosurgical unit (Jennett \& MacMillan, 1981; Scottish Head Injury Management Study, 1977). Thus, vast numbers of patients with apparently minor head injuries are admitted to hospital in order to detect the very small number that will subsequently develop an intracranial haematoma or other serious complications. A considerable amount of research has been undertaken into those factors indicating the risk of an intracranial haematoma. The roles of coma scales,

Correspondence: Paul L. Milsom, Consultant, Accident and Emergency Department, York District Hospital, Wigginton Road, York YO3 $7 \mathrm{HE}$, England. 
assessment charts, CT scans and skull $\mathrm{X}$-rays have all been evaluated (Teasdale \& Jennett, 1974; Marsden et a1., 1985; A Group of Neurosurgeons, 1983; Royal College $\frac{\mathbb{Q}}{0}$ of Radiologists, 1983; Mendelow et al., 1983). Despite this, many patients die $\frac{3}{D}$ unnecessarily as a result of intracranial haematomas. The most common avoidable factor is delay in treatment (Rose et al., 1977; Jeffreys \& Jones, 1981), and it has been clearly shown that delay measured from the onset of deterioration of conscious level is related closely to morbidity and mortality (Mendelow et al., 1979).

Echoencephalography has been practised for 30 years but fell into disrepute when early equipment was used by inexperienced operators and unreliable results were obtained. More recently, a computerized echoencephalograph, the Midliner, has been developed. This automatically identifies the echo patterns from both the midline structures and the inner surfaces of each side of the skull and calculates any discrepancies between the actual and theoretical midline positions. This process is rapid, enabling a series of readings to be taken within a few minutes. These readings are plotted manually or automatically, depending on the equipment, to produce a histogram and a modal value (Fig. 1). It is much more reliable and is not subject to operator error, yet has still not gained wide acceptance.

\section{METHOD}

The senior house officers in the authors' A\&E Department were advised to make liber use of the Midliner as part of their assessment of head-injured patients although n⿳亠丷厂

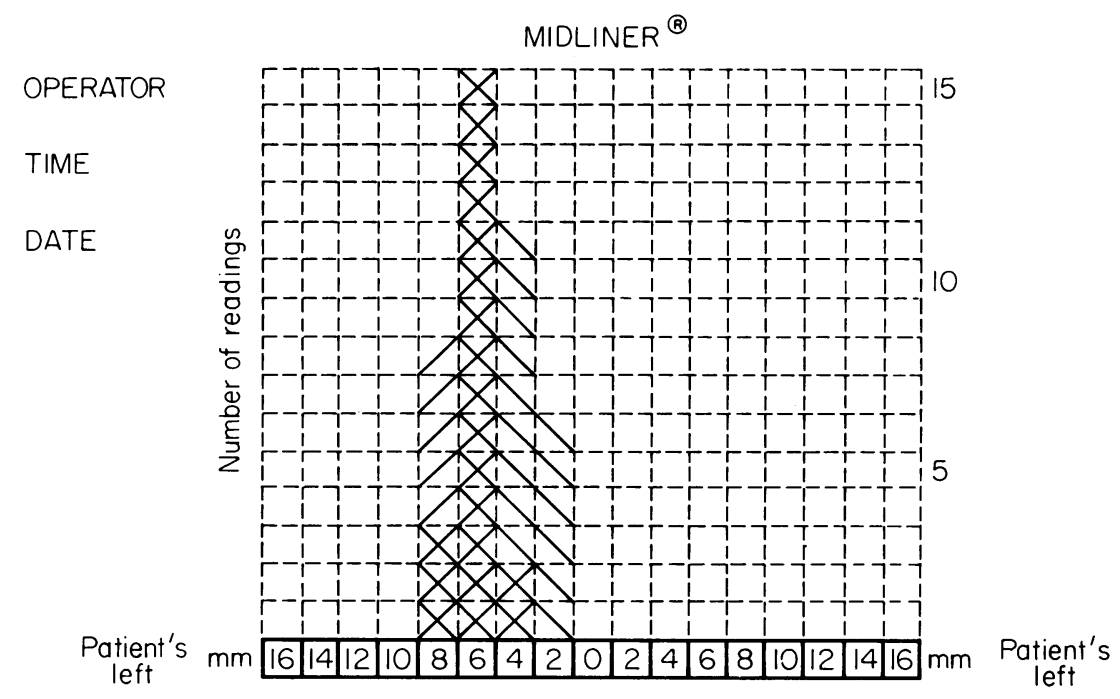

COMMENTS

PATIENT'S NAME

HOSPITAL NO.

Fig. 1 Echoencephalogram showing a midline shift of $6 \mathrm{~mm}$. 
definitive indications had been suggested. The records of all the patients who had a Midliner examination in the A\&E department in 1984 were retrospectively reviewed.

\section{RESULTS}

Eight hundred and eighty-four Midliners were requested in the A\&E department, but the records of ten patients were missing and have, therefore, been excluded from the study.

The histogram (Fig. 2) shows the age distribution of the patients. This is very similar to that of all head injury attenders in the UK and it emphasizes that over half are under the age of 20 (Jennett \& MacMillan, 1981).

Of these 874 Midliners, nine (all from adults) were declared technically 'unobtainable' without explanation. Only 10 Midliners were considered to be either incomplete or inconclusive, with less than 30 readings at the modal value.

Thirteen patients had a Midline shift of $1 \mathrm{~mm}$ or more on admission. Of these, only one proved to have a haematoma but, of the remaining 12, four (all children) had other pathology to account for their shift (Table 1). The remaining 842 midliners were normal and showed no shift.

There were only five patients in this study who developed an intracranial haematoma (Table 2). Three of these were in coma on arrival; the other two were fully conscious. Of the three comatose patients, Midliners were 'unobtainable' in two, and were abandoned in favour of an urgent CT scan which showed acute unilateral subdural haematomas. The other comatose patient had extensive skull fractures and a CT scan confirmed the ultrasound evidence of no shift and demonstrated bilateral haematomas (one extradural and one intracerebral).

Both conscious patients developed an extradural haematoma. One had no skull fracture and, when first seen in the A\&E department, no midline shift, but he slowly developed a shift as a result of a less acute haemorrhage; the other had a midline shift of $4 \mathrm{~mm}$ and a skull fracture. A detailed account of these two cases is instructive.

\section{Case Report 1}

An 8-year-old boy who fell in the school playground was knocked out but regained full consciousness within a few minutes. On arrival in the A\&E department, he was amnesic

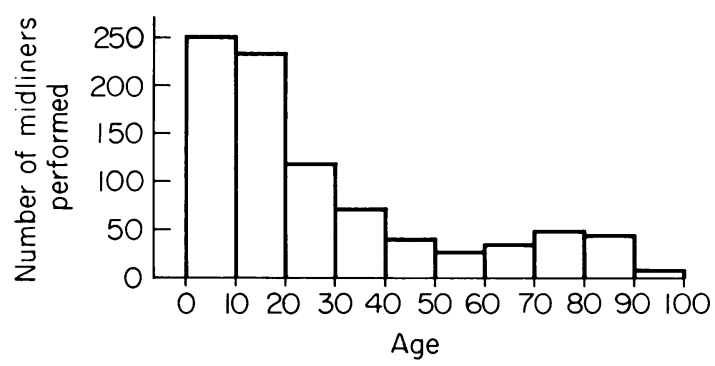

Fig. 2 Histogram showing the age distribution of the patients who had a Midliner examination. 
Table 1 Patients with a Midline shift as demonstrated by the echoencephalogram

\begin{tabular}{|c|c|c|c|c|}
\hline Sex & Age & $\begin{array}{c}\text { Skull } \\
\text { fracture }\end{array}$ & $\begin{array}{l}\text { Midline shift } \\
\quad(\mathrm{mm})\end{array}$ & Outcome \\
\hline $\mathbf{M}$ & 6 weeks & Yes & 4 & Primary brain injury \\
\hline $\mathbf{M}$ & 2 & No & 2 & $\begin{array}{l}\text { Craniectomy one year earlier for } \\
\text { craniosynostosis }\end{array}$ \\
\hline $\mathbf{M}$ & 2 & No & 2 & $\begin{array}{l}\text { Residual hemiparesis resulting from T.B. } \\
\text { meningitis }\end{array}$ \\
\hline $\mathbf{F}$ & 3 & No & 2 & Posterior fossa tumour \\
\hline $\mathbf{F}$ & 5 & No & 2 & False positive \\
\hline $\mathbf{F}$ & 14 & No & 2 & False positive \\
\hline $\mathbf{M}$ & 20 & No & 2 & False positive \\
\hline $\mathbf{M}$ & 21 & No & 2 & $\begin{array}{l}\text { Echo repeated three times; no midline shift by } \\
\text { the following day }\end{array}$ \\
\hline $\mathbf{M}$ & 28 & No & 2 & False positive \\
\hline $\mathbf{F}$ & 33 & Yes & 4 & Extradural haematoma \\
\hline $\mathbf{F}$ & 41 & No & 1 & False positive \\
\hline $\mathbf{M}$ & 50 & Yes & 1 & False positive \\
\hline $\mathrm{F}$ & 83 & No & 4 & False positive \\
\hline
\end{tabular}

for the event and vomiting, but there were no focal neurological signs. Skull X-rays did not show a fracture. The Midliner at this stage did not show any shift but the casualty officer stated that the Midliner was 'equivocal, repeat in $2 \mathrm{~h}$ '. The Midliner at 6-h pose injury showed a $2-\mathrm{mm}$ shift but this was not thought to be significant. The patien continued to be observed on the ward for a further $27 \mathrm{~h}$, after which time there had bee a 'definite but mild deterioration in the level of consciousness'. Another Midliner at $33 \mathrm{~h}$ showed a 6-mm shift. An extradural haematoma was confirmed on the CT scan and then evacuated. There were no focal neurological signs at any stage.

\section{Case Report 2}

A 33-year-old female was brought to the A\&E department approximately one hour after sustaining a 'minor' head injury. She had been briefly unconscious, but had a headache

Table 2 Patients with an intracranial haematoma

\begin{tabular}{|c|c|c|c|c|c|}
\hline Sex & Age & $\begin{array}{c}\text { Skull } \\
\text { fracture }\end{array}$ & $\begin{array}{l}\text { Midline shift } \\
\qquad(\mathrm{mm})\end{array}$ & Coma & Outcome \\
\hline $\mathbf{M}$ & 8 & No & 0 & No & $\begin{array}{l}\text { Extradural haematoma; full } \\
\text { recovery after evacuation }\end{array}$ \\
\hline $\mathrm{F}$ & 50 & Yes & 0 & Yes & $\begin{array}{l}\text { Bilateral haematomas (extradural } \\
\text { and intracerebral); died }\end{array}$ \\
\hline $\mathbf{M}$ & 59 & No & Unobtainable & Yes & Acute subdural haematoma; died \\
\hline $\mathbf{F}$ & 33 & Yes & 4 & No & $\begin{array}{l}\text { Extradural haematoma; full } \\
\text { recovery after evacuation }\end{array}$ \\
\hline $\mathbf{F}$ & 77 & Yes & Unobtainable & Yes & $\begin{array}{l}\text { Acute subdural haematoma; } \\
\text { survived with severe brain damage }\end{array}$ \\
\hline
\end{tabular}


and minimal amnesia. There were no focal neurological signs and her slight impairment of consciousness was only detectable on a sensitive coma scale. She had a skull fracture and a 4-mm shift. She was admitted for observation, $3 \mathrm{~h}$ later developed equivocal weakness of one leg and, in the absence of a functioning CT scanner, was taken directly to theatre for evacuation of her large extradural haematoma.

Both of the above patients made a complete and uneventful recovery but, if their Midliner results had been believed, both haematomas could have been diagnosed earlier.

In this series, there were 51 patients with a skull fracture reported by the casualty officer. This seems a high proportion $(5 \cdot 8 \%)$ but this is a selected group of patients. In fact, there were 2204 skull X-rays carried out in the department in 1984, giving an incidence of skull fracture $(2 \cdot 3 \%)$ closer to that which would be expected (Royal College of Radiologists, 1983).

Of the 874 patients in the study, 19 were admitted to the neurosurgical unit and 380 were admitted for observation only.

\section{DISCUSSION}

In a review of patients transferred to a neurosurgical unit (Price, 1983), the haematomapredictive power of a variety of clinical and radiological features was examined. The three most sensitive indicators were shown to be:

(1) increasing midline shift;

(2) initial midline shift of $1 \mathrm{~mm}$ or more; and

(3) decreasing conscious level.

There was also a clear relationship between degree of shift and the probability of haematoma (Price, 1985; Salem \& Price, 1982).

If these had been used as indications for a CT scan in these patients, both extradural haematomas would have been diagnosed earlier; $27-\mathrm{h}$ earlier in the first patient and 3-h in the second. Neither patient would have been subjected to the potential risks associated with delayed treatment (Mendelow et al., 1979).

The Midliner investigation is relatively inexpensive, tolerates restless patients and takes little time. Serial investigations can be performed, as with an electrocardiogram, with the portable equipment. It has been suggested that there is little point in requesting a Midliner when CT scans are readily available. However, it is clearly impossible to scan the 200000 patients admitted after head injury in Britain every year. It is now common practice to scan patients with 'minor' head injuries only after deterioration in conscious level or development of other neurological signs. This traditional policy may well account for many of the estimated 700 patients who died with unexpected haematomas each year (Jeffreys \& Jones, 1981; Price, 1983; Teasdale, 1984). The present authors believe that the routine use of the Midliner will enable them to select those patients at risk of developing a haematoma at a much earlier stage before secondary brain damage occurs as a result of distortion and raised pressure.

There are now clear guidelines (A Group of Neurosurgeons, 1983) on the indications for admission to hospital after head injury in adults. It seems reasonable to do a Midliner only if admission is already indicated. To do otherwise challenges the 
guidelines. If this criterion had been applied, only 399 Midliners would have been done in 1984.

Is it worth carrying out 399 Midliners to help with the early diagnosis of two extradural haematomas? Three hundred and eighty patients were admitted to hospital and 2204 had skull $\mathrm{X}$-rays in order to diagnose the same two haematomas. In the light of this, the authors feel that it is not unreasonable to carry out a further (inexpensive) investigation if it reduces the number of deaths from extradural haematoma.

\section{REFERENCES}

A Group of Neurosurgeons (1983) Guidelines for initial management after head injury in adults. British Medical fournal 288, 983-5.

Jeffreys R. V. \& Jones J. J. (1981) Avoidable factors contributing to the death of head injury patients in general hospitals in Mersey Region. Lancet ii, 459-61.

Jennett B. \& MacMillan R. (1981) Epidemiology of head injury. British Medical fournal 282, 101-4.

Marsden A. K., Staniland J. R. \& Price D. J. (1985) Development of a coma scale for emergency care. fournal of the World Association for Emergency and Disaster Medicine 1 (Suppl. 1), 249-51.

Mendelow A. D., Karmi M. Z., Paul K. S., Fuller G. A. \& Gillingham F. J. (1979) Extradural haematoma: effect of delayed treatment. British Medical fournal 1, 1240-2.

Mendelow A. D., Teasdale G., Jennett B., Bryden J., Hessett C. \& Murray G. (1983) Risks of intracranial haematoma in head injured adults. British Medical fournal 287, 1173-6.

Price D. J. (1983) A comparative study of the predictive capabilities of clinical and radiological features. Im $\infty$ The Management of Acute Head Injury, 77-82, Fenton Lewis A. (ed.), DHSS (Harrogate Seminars 8) London.

Price D. J. (1985) Computerised ultrasound for the monitoring of head injured patients. Intensive Care World 2, 88-91.

Rose J., Valtonen S. \& Jennett B. (1977) Avoidable factors contributing to death after head injury. British Medical fournal 2, 615-18.

Royal College of Radiologists (1983) Patient selection for skull radiography in uncomplicated head injury. Lancet i, 115-19.

Salem F. \& Price D. J. (1982) Monitoring of head injuries. In Modern Neurosurgery 1, Brock M. (ed.), 44-50. Berlin. Springer-Verlag.

Scottish Head Injury Management Study (1977) Head injuries in Scottish hospitals. Lancet ii, 696-8.

Teasdale G. (1984) Head injuries are badly managed in accident and emergency departments and neurosurgeons are partly to blame. Archives of Emergency Medicine 3, 123-4.

Teasdale G. \& Jennett B. (1974) Assessment of coma and impaired consciousness: a practical scale. Lancet ii, $81-4$. 